\title{
LODPRO: learning objects development process
}

Leandro Marques Queiros ${ }^{1 *}$, Denis Silva da Silveira², Jorge da Silva Correia-Neto ${ }^{1}$ and Guilherme Vilar ${ }^{1}$

\begin{abstract}
Background: Research concerning to the use of technology in education has received increasing attention from scholars in recent years. This attention has resulted in new educational materials demanding creative ways to plan, develop, distribute, and evaluate them.

Methods: This paper integrates software innovation and management approaches, resulting in an innovative, efficient methodology for the development of learning objects (LOs). The process proposed in this research paper was applied in a case study in which two health-related LOs were developed.

Results: The process proposed in this study is called Learning Objects Development Process - LODPRO. This work contributes to both theory and practice in the development of LOs, a field in which innovative techniques such as Design Thinking and the Business Model Canvas are fundamental.

Conclusions: Based on these results, we conclude that the present study offers a significant contribution to both theory and practice in this field. If used as a method to develop LOs that focus innovation, the techniques of Design Thinking and Business Model Canvas become fundamental parts of the process.
\end{abstract}

Keywords: Learning objects, Innovation in software design, Software engineering

\section{Background}

Research concerning the use of technology in education has received increasing attention from scholars in recent years. This recent attention has resulted in the transformation of educational materials and the way in which they are planned, developed, distributed, and evaluated. Considering the ease of creating them, learning objects (LOs) have emerged in an attempt to support the teaching process and to disseminate learning through educational content [1]. However, the concept of LOs is polysemic; examples of LOs range from small resources (such as the paragraph of a text) to very large resources (such as an entire training course in a teaching technique) [2]. Broadly speaking, LOs are digital or nondigital instruments used for learning, teaching, or training [3]. For the purposes of this paper, LOs are digital artifacts-in the shape of information bits-which

\footnotetext{
* Correspondence: leandromarquesrr@gmail.com

'Department of Statistics and Informatics, Federal Rural University of

Pernambuco, Recife 52171-900, Pernambuco, Brazil

Full list of author information is available at the end of the article
}

can be used-either individually or as part of a larger effort-to aid learning processes.

Because they are digital artifacts, LOs are very closely related to software [4]. Both of them share similar characteristics in their development and production. To ensure that software is being developed according to their specifications, we must first establish procedures, methods, and objects to be utilized in their development [5]. Therefore, we insist that methodologies and practices in software engineering should also support the development of LOs. Software engineering, however, on its own is not enough to meet all the needs of those developing educational artifacts [6], calling for the need to identify more specific alternatives.

Given the issue previously discussed, Chalegre et al. [7] point to the agile methodology as a possible solution. Among other things, this methodology aims to reduce the length and costs to develop software, improve the quality of the final product, adapt to changes, promote daily tasks to reach a final goal, include the client in the development process, and fully integrate the development team. Through these, the agile methodology 
aims to improve and support the development of LOs, especially as it concerns design difficulties and issues with the multidisciplinary nature of LOs.

To fully support this methodology, this paper integrates four dimensions: software engineering, innovative approaches, business management, and quality management, always seeking elegant solutions that address users' expectations [8]. As of 2014, a search on the international databases of IEEE Xplore ${ }^{\circ}$ Digital Library and Scopus, as well as the Annals of the Brazilian Informatics Symposium, did not yield any conceptual frameworks that included the four previously mentioned dimensions being used in the development of LOs.

This study proposes a process for the development of digital LOs. In this paper, we address the following research questions: considering these four dimensions, which methods and techniques should aid in the development of LOs? How should we integrate these methods and techniques in the development of LOs? This paper is divided into six sections: this introduction, a literature review, related studies, methodology, results, and final considerations (including recommendations for future research).

\section{Literature review}

In our review, we investigated the current state-of-theart in four areas: learning objects, software engineering, total quality management, and innovative approaches.

\section{Learning objects}

There are no formal, universal definitions for LOs; there is only a consensus among scholars that these objects must have an educational purpose [9]. The term "learning objects" was originally used by Wayne Hodgins, in 1994, in the CedMA research group named Learning Architectures, Application Programming Interface, and Learning Objects, which became a reference in the field of computer-assisted learning [10].

LOs are closely related to the object-oriented paradigm (OOP), given that this paradigm helps to manage and to maintain the code [11] and increases its capacity for reutilization, maintenance, recovery, and sharing [12]. Thus, LOs are flexible, because they can be easily increased without overcomplicating their level of abstraction or compromising their efficacy [13].

\section{Software engineering}

Software engineering is a method for developing and maintaining systems. Some of its characteristics there is the fact that is a dynamic process; it allows for effective quality control; and it fosters productivity, planning, and management of activities, as well as resources, costs, and deadlines [14]. Software engineering is also a discipline that establishes the principles of engineering, aiming to develop products in a systematic manner, resulting in an effective, trustworthy product [5].

Software engineering, however, in its traditional manner, can only be applied in circumstances in which the system specifications are stable. The lack of that requirement suggests the use of agile methodologies, justifying the use of these methodologies in the present work [15].

The term "agile methodology" emerged in 2001, as specialists in software proposed new techniques and tools to improve software development while compromising as little as possible in quality and project documentation [16]. Agile projects must have the following characteristics [17]:

- Processes and tools are replaced by individuals and interactions.

- Extensive documentation is replaced by a working software.

- Contract negotiation is replaced by collaborating with the client.

- Following a plan is replaced by adapting to changes.

The most well-known agile methodologies are: Scrum, Agile Documentation, Crystal Clear, Dynamic Systems Development Method (DSDM), and eXtreme Programming (XP). In this study, we chose to use Scrum; its benefits are evident given that it increased productivity by over $80 \%$ and project quality by $40 \%$ while decreasing cost by $25 \%$ [Cohn 2010, apud [18]].

The smaller piece of the development cycle of a Scrum project is called "sprint" and is defined by iterations that can last 2 to 4 weeks, allowing the project in question to be versioned at the end of each sprint or to continue being improved in the subsequent iteration [19]. Scrum implements a framework in which activities are conducted by people that assume three core roles [20]: Product Owner, Scrum Master, and the Development Team.

\section{Total quality management}

The Plan, Do, Check, and Act cycle (PDCA) is centered around total quality management (TQM) [21]. Shewhart (1931) was responsible for introducing PDCA concepts and the logic of this cycle. However, it was his pupil, Edward Deming, who developed many of the quality management techniques in which PDCA is based. Therefore, the technique is also known as Deming's cycle, and over the years, Deming became one of the most important scholars of this area [22].

The PDCA cycle starts with a Plan, which refers to the planning stage of the project. The execution of the planned actions corresponds to the Do stage. The next step, Check, analyzes whether what was produced corresponds to what was planned. Finally, the Act stage 
includes mitigating possible mistakes or flaws in the product or its execution processes [23].

\section{Innovative approaches}

This section presents the main innovative approaches to software projects aimed at providing a better understanding of them and to present possible elements that can be added to the development of LOs.

\section{Business Model Generation}

The business model is an abstraction about how a business should work and how the organization creates, captures, and delivers value. Therefore, it is of key importance to have a business model that can be understood by all parties involved in the software innovation, and that is not overly complex to the point of negatively affecting the project $[24,25]$.

Business Model Generation (BMG) is a methodology that works as a guide that inspires the creation of a new business model or the improvement of an existing one. One of BMG's tools is the Business Model Canvas (BMC), which is simple, comprehensible, and used by many large organizations [26]. The tool consists of nine steps, aimed at capturing different elements involved in the business model, as well as ideas to facilitate the understanding of the project at hand [27]. These steps are customer segment, value proposition, communication channels, customer relationships, revenue streams, key resources, key activities, key partnerships, and cost structure.

\section{Business Process Management}

Business Process Management (BPM) can be used in a myriad of contexts. Oliveira et al. [28] defined BPM as a collection of methods, techniques, and technologies that assist organizations in managing their business; this collection can be used to design, analyze, execute, and control business processes and can, among other things, be shaped by Business Process Model and Notation (BPMN).

BPMN is a graphic notation for specifying business processes; according to Gonçalves et al. [29], BMPN's main objective is to give representation to users while also representing the complex semantics of processes. The graphic notation elements of BPMN are used to model most business processes [30] and were used in this study to support the development process of LOs.

\section{Design Thinking}

Design Thinking is a model for organizational innovation that has its own characteristics; it proposes a new mental model to the organization and has as its main advantage the development of creative solutions-which use usercentered research methods to address organizational strategic challenges, given in Table 1 [31].

\section{Related research}

Some methods are generically used in the development of didactic-pedagogic content, other methods are solely used for the development of software, and there are others that were designed specifically for LOs [4]. This section presents works that are related to the content and context of this study.

A study by Amaral et al. [32] presents the steps for the development of LOs used by the Rede Internacional Virtual de Educação (International Network for Virtual Education-RIVED) and stresses the importance of team interaction and of using storyboards to route the development of LOs.

Pessoa and Benitti [33] discuss the elements included in the development process of LOs, focusing on the project's conception, development, and distribution, but they do not cover innovative approaches to software development.

Finally, the Analysis, Design, Development, Implementation and Evaluation Model (ADDIE), presented in a study by Branch [34], it is commonly employed in the creation of LOs, but it is not used in innovative approaches to product conception.

Some desirable attributes should be present in the LO's development process from the perspective of innovation approaches, multidisciplinary, and reuse. Table 2 shows the dimensions and points out if they are present or not in LO's development processes presented in this section.

Table 1 Description of Design Thinking tools

\begin{tabular}{ll}
\hline Tool & Description \\
\hline Analysis and synthesis & $\begin{array}{l}\text { The analysis is very important to break down complex issues as a way of better understanding them; yet, the creative } \\
\text { process is based on synthesis or the collective act to join parts in the creation of complete ideas. } \\
\text { Brainstorming }\end{array}$ \\
$\begin{array}{l}\text { Pery necessary when the goal is to obtain a wide range of ideas. } \\
\text { Storyboard }\end{array}$ & A prototype is any tangible object that allows for the exploration, evaluation, and development of an idea. \\
\hline
\end{tabular}


Table 2 Approach of the processes used in the development of LO

\begin{tabular}{llll}
\hline Categories & \multicolumn{2}{l}{ Learning object's development process } \\
\cline { 2 - 4 } Dimensions & RIVED & SOPHIA & ADDIE \\
\hline Continuous improvement & No & No & Yes \\
Brainstorm & No & No & No \\
Business modeling & No & No & No \\
Project management & No & No & No \\
Reuse & No & Yes & No \\
Teaching skills & Yes & Yes & Yes \\
Educational evaluation & Yes & No & Yes \\
Usability & No & Yes & No \\
\hline
\end{tabular}

\section{Conceptual framework}

Figure 1 describes the conceptual framework used in this study, which stemmed from studies on innovative approaches from Design Thinking (tools: insight cards, conceptual map, brainstorming, mind mapping, and storyboard) and BMG (tool: Canvas), as well as PDCA, software engineering (through the agile methodology using the Scrum method and project analysis) and BPM (tool: BPMN). All of them were used in the development process of the LOs discussed in this study.

\section{Methods}

We first conducted a literature search covering themes related to this study, more specifically: LOs, software engineering, agile methodology, BMG, BPM, and Design
Thinking. We also searched for related works and possible gaps in the literature.

The selection of themes included in this study used a criterion that emerged from literature search, defined as a way to assure that the results would address the research questions and objectives proposed in this study.

Based on the selected elements from each of the four dimensions covered in the literature review, we established the development process for the LOs, here called learning object's development process (LODPRO). This process was later validated through a case study detailed in the next section.

The present study aimed to demonstrate the applicability of the proposed process, which utilized all of the previously defined instruments. This process offers guidance to those interested in developing LOs, discussing the planning, execution, development, and evaluation phases. Further details on the process will be presented in the discussion section.

\section{Results and discussion}

\section{The proposed process}

The process proposed in this study, which is drawn in Fig. 2, is called LODPRO. It consists of the insertion of tasks in the "Plan" phase of the PDCA cycle-given that a well-executed plan avoids flaws and unnecessary time loss in the following phases of the cycle. Another phase is "Do," which executes the task planned in the previous phase. The "Check" phase verifies and analyzes the results obtained in the process. Finally, the "Act" phase

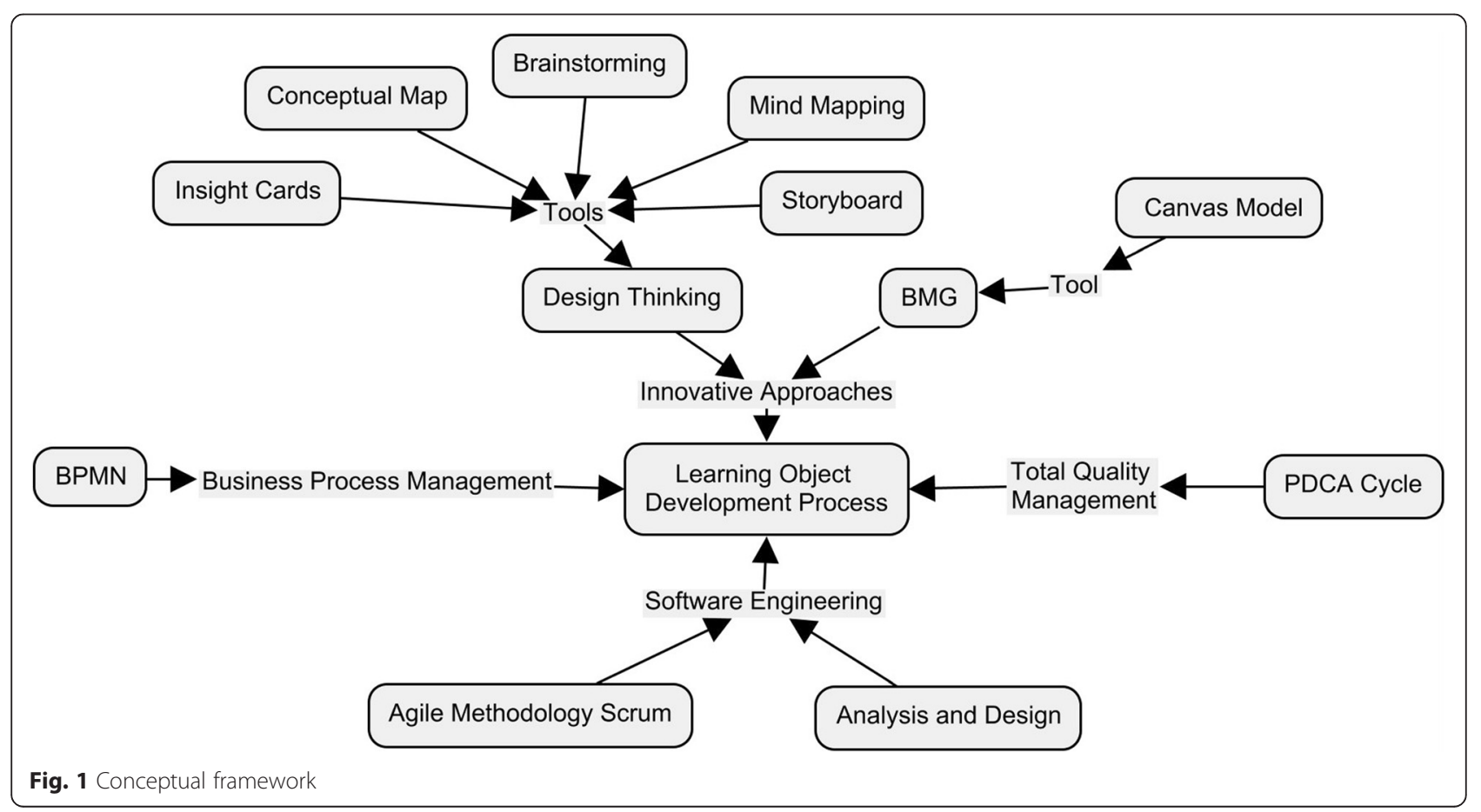




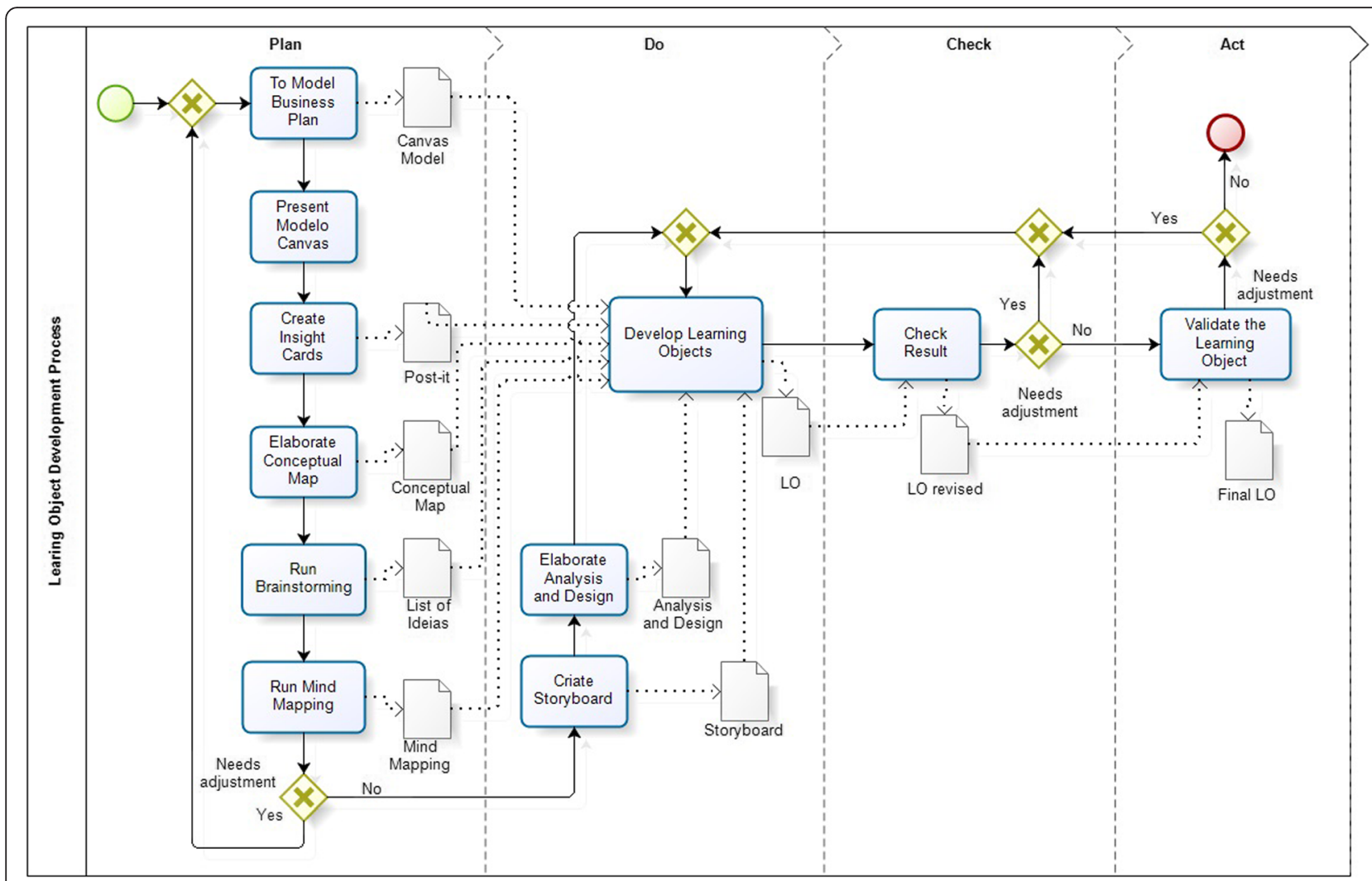

Fig. 2 LODPRO: learning object's development process

reflects on the reason for deviations and devises possible corrective actions, such as altering the business model.

\section{Case study on the process' application}

Based on LODPRO, we established the roles of the Development Team, a team of five individuals (two being physicians/customers and three being developers). The team met bi-weekly for 10 weeks in a local hospital that was well-known in the study site (Recife, Brazil); they also met weekly using $S k y p e^{\oplus}$.

First, the stakeholders identified the need for and the relevance of LOs that represented the extra-uterine and intra-uterine circulations. As defined by LODPRO, the development process of the LOs begins by creating a business plan ("Plan" phase), which happens during the immersion phase. The project team created this business model using the Business Model Canvas tool. After its creation, the plan was presented to stakeholders involved in the project, who herein on will be called "customers." While the Scrum Master used Canvas to present the model to the customers, the customers registered their insights in insight cards. This represents the last step of the immersion phase.

The analysis and synthesis phase begins with the creation of a conceptual map by the customers, using both the presented Canvas and the ideas contained in insight cards. We used the brainstorming technique and selected a participant to act as a moderator. The customers came up with a multitude of ideas, and from these, a catalog was developed; the catalog contained a synthesis of all the ideas created in the project.

In this first task of LODPRO, the team of the project and the stakeholders (customers, users, investors, sponsors, etc.) must meet in order to develop the Canvas model. The model of this tool describes how an organization creates, delivers, and captures values for

Table 3 Task specification to model the business plan

Task: to model the business plan

Purpose: develop a business plan

Responsible: team with the help of stakeholders Input

Product work: Description: document that describe the strategies and business plan organizational goals

\section{Output}

Product work: Description: it describes how the logical organization business model creates, delivers, and captures values

$$
\text { Tool }
$$

Name: Business Purpose: illustrate and comment on Source approach: Model Canvas the overview of the business model BMG 
the target audience. It is important to emphasize that those responsible for creating the Canvas model may change according to the project. For example, the supplier may present the Canvas model already finalized for an investor. Table 3 shows the specification of this task.

The "Do" phase began with the creation of a storyboard using the data collected during the previous phases and following a story line. We decided that two virtual LOs would be developed using the basic techniques of graphic design and sequential narration of images and text. In the analysis phase, we mapped products that had been previously created to understand their specifications and designs.

Table 4 shows the task specification develop storyboard. In this task, the Scrum Master must coordinate the Development Team (DT) to produce the storyboard. The DT should prepare a written script and then separate the story into sections, taking into account the scenarios, actors, and frameworks that will be used to represent what you want. Finally, we choose the imaging technique available or most suitable for the purpose, depending on the outcome, that may be printed or digital. It is important to visually represent what you want to communicate.

The "Check" phase aimed to evaluate whether the LOs matched the previously agreed upon specifications. In the LOs that the team developed, we identified the need for improving color tones and also for adjusting the position of text presented in the videos. Therefore, the process returned to the development phase, where the necessary adjustments were made. The resulting LOs were evaluated once again, and we concluded that they matched the specifications of the project, therefore ending this phase. See Table 5.

The "Act" phase corresponds to the validation of the LOs, in which we would try to validate the LOs along with the customer and users. It was not possible to enact

Table 4 Task specification develop storyboard

\begin{tabular}{|c|c|c|}
\hline \multicolumn{3}{|l|}{ Task: develop storyboard } \\
\hline \multicolumn{3}{|c|}{ Purpose: to prepare presentation script } \\
\hline \multicolumn{3}{|c|}{ Responsible: Scrum Master } \\
\hline & \multicolumn{2}{|l|}{ Input } \\
\hline \multirow{2}{*}{$\begin{array}{l}\text { Product work: business } \\
\text { model, insight cards, } \\
\text { conceptual map, and } \\
\text { menu ideas }\end{array}$} & \multicolumn{2}{|c|}{$\begin{array}{l}\text { Product work: have to guide the } \\
\text { business model Canvas, insight cards, } \\
\text { conceptual map, and menu ideas }\end{array}$} \\
\hline & Output & \\
\hline \multirow[t]{2}{*}{$\begin{array}{l}\text { Product work: } \\
\text { script scenes }\end{array}$} & \multicolumn{2}{|c|}{$\begin{array}{l}\text { Description: transposition script scenes, } \\
\text { illustrated in scenarios and actors }\end{array}$} \\
\hline & \multicolumn{2}{|l|}{ Tool } \\
\hline $\begin{array}{l}\text { Name: paper } \\
\text { and pencil }\end{array}$ & $\begin{array}{l}\text { Purpose: a visual } \\
\text { representation of a story } \\
\text { through still frames }\end{array}$ & $\begin{array}{l}\text { Source approach: } \\
\text { Design Thinking }\end{array}$ \\
\hline
\end{tabular}

Table 5 Task specification check learning object

Task: check learning object

Purpose: verification of learning object

Responsible: Scrum Master

$\begin{array}{ll} & \text { Input } \\ \text { Product work: learning } & \text { Description: verification of learning } \\ \text { object developed } & \text { object developed } \\ & \text { Output }\end{array}$

Product work: learning object Description: checking if the learning object is according to requirements

this phase due to the limited availability of stakeholders. Therefore, there is a need for future studies that address the validation of the process proposed in the present study.

If identified by users/clients need some adjustment, it is possible to return to the development stage of the LOs and perform whatever is necessary. In sequence, it continues the process and triggers the Check stage again, returning to the validation phase. Table 6 shows the specification of this task.

Given that our LO is a digital video, we present two figures to illustrate the LOs developed. Figure 3 corresponds to the fetal circulation LO, and the Fig. 4 is the extra-uterina circulation LO. Full previews of the LOs are available on YouTube. Fetal circulation is available at http://youtu.be/-1TE3xo6nv4 and extra-uterina circulation is available at http://youtu.be/O9AZvQKBJ7s.

\section{Conclusions}

The literature review was the first step in developing the LOs here discussed. In this study, we applied techniques and tools used in innovative approaches. We also included methodologies from business management and software engineering. Based on the fundamental characteristics and definitions of LOs, we established 11 steps: create a business plan, present it using Canvas, create insight cards, elaborate a conceptual map, run brainstorming session, make the mind map, create the

Table 6 Task specification validate learning object

\begin{tabular}{l} 
Task: validate learning object \\
$\begin{array}{l}\text { Purpose: validation of learning object } \\
\text { Responsible: users/clients } \\
\end{array} \quad \begin{array}{l}\text { Input } \\
\text { Product work: learning } \\
\text { object }\end{array}$ \\
$\begin{array}{ll}\text { learning object developed } \\
\text { Ofoduct work: feedback }\end{array}$ \\
$\begin{array}{l}\text { Description: users/clients give the feedback } \\
\text { if the learning object is developed } \\
\text { according to expected or if it needs to } \\
\text { make adjustments in learning object }\end{array}$ \\
\hline
\end{tabular}




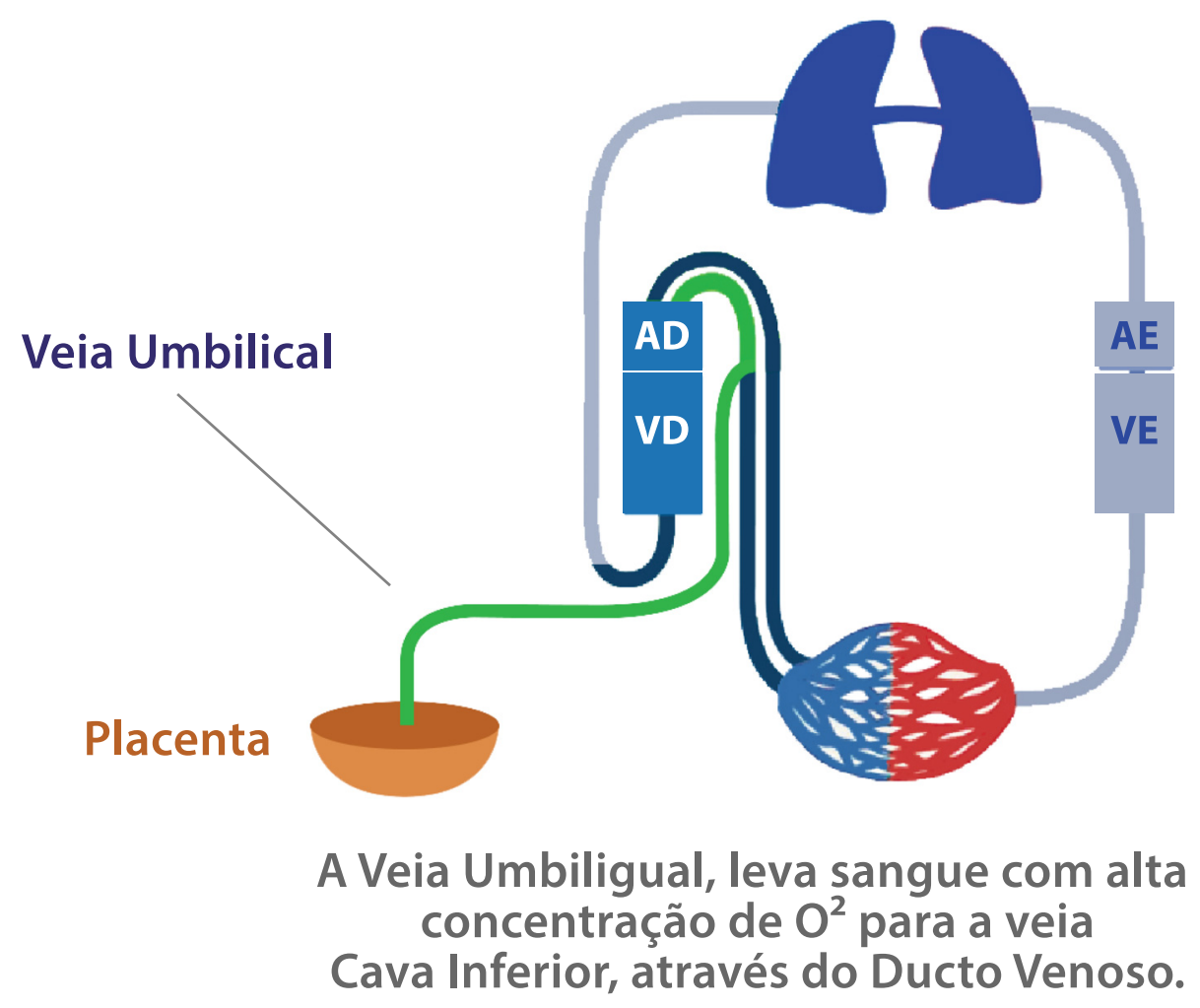

Fig. 3 Schematic view of fetal circulation

storytelling, analyze the project, develop the learning tool, verify results, and validate the learning tool.

The main aim of this study was to propose a development process for LOs that took into consideration aspects of software engineering, innovative approaches, business process management, and total quality management, hoping to accelerate the software development while also mitigating losses in quality and project documentation. We observed that, in some situations, it was necessary to return to previous phases of the process. As an example, when the evaluation of the LO indicated the need for improvements, calling for a return to the previously concluded development phase.

When the stages and steps in the process which needed to be adjusted were defined, the need to graphically represent the process emerged; that is, the need for

Scene: First visualization of the heart and then the same screen, another schematic view of the heart, the transition time and arrow.
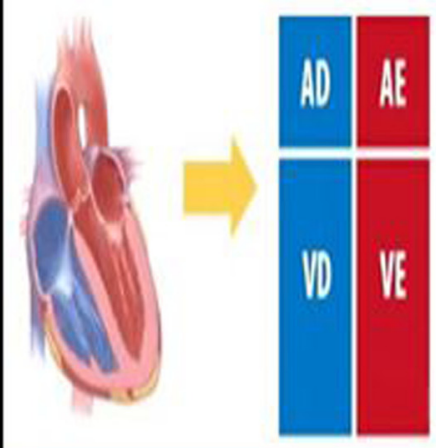

Fig. 4 Schematic view of the heart 
creating visual elements that represented the LO's development process. Considering the findings of the literature review on innovative approaches, we found the need for using BPM. This tool aims to provide a graphic representation that is user-friendly and intuitive when representing the complex semantics of the processes [29]. Analysis of the characteristics and objectives at each stage concluded that they should be divided in phases; therefore, we decided to use the Plan, Do, Check, and Act phases from the PDCA cycle.

The proposed process also made use of elements from the agile methodology Scrum to manage the project, and given the aforementioned specifications, we could achieve a building process for the development of the LOs in question.

Based on these results, we conclude that the present study offers a significant contribution to both theory and practice in this field. If used as a method to develop LOs that focus innovation, the techniques of Design Thinking and Business Model Canvas become fundamental parts of the process. This work has also indicated the need for future studies that (i) define roles responsible for executing tasks and (ii) evaluate other innovative tools in a new case study, given that there is a wealth of approaches that are heavily adopted by the market.

\section{Competing interests}

The authors declare that they have no competing interests.

\section{Authors' contributions}

LMQ is the main author of this paper, which is the result of his Master Degree Dissertation at Federal Rural University of Pernambuco (Brazil). GV is LMQ's research adviser and was the responsible to guide the research. JSCN and DSS contributed to the writing and revising of the manuscript, and they are also accountable for all aspects of the work. All authors read and approved the final version of the manuscript.

\section{Acknowledgements}

This study was financed by the Brazilian Agency "Coordenação de Aperfeiçoamento de Pessoal de Nível Superior - CAPES."

\section{Author details}

'Department of Statistics and Informatics, Federal Rural University of Pernambuco, Recife 52171-900, Pernambuco, Brazil. ${ }^{2}$ Center of Applied Social Science, Federal University of Pernambuco, Recife 50740-580, Pernambuco, Brazil.

Received: 23 September 2015 Accepted: 15 June 2016

Published online: 19 July 2016

\section{References}

1. Rocha FL, Moraes H, Fabri LB, Oliveira TDJ, Costa AC, Netto CM, Morais RC (2011) Repositórios de objetos de aprendizagem-um estudo exploratório. In: Anais do Simpósio Brasileiro de Informática na Educação

2. Barritt C, Alderman Jr. FL. (2004) Creating a Reusable Learning Objects Strategy: Leveraging Information and Learning a Knowledge Economy. USA: John Wiley \& Sons

3. IEEE (2002) Draft standard for learning object metadata. Institute of Electrical and Electronics Engineers. Learning Technology Standards Committee (LTSC). 1484.12.1-2002

4. Braga J, Dotta S, Pimentel E, Stransky B (2012) Desafios para o Desenvolvimento de Objetos de Aprendizagem Reutilizáveis e de
Qualidade. In: Anais do Workshop de Desafios da Computação Aplicada à Educação., pp 90-99

5. Pressman R. (2010) Software engineering: a practitioner's approach, 7th edn. McGraw-Hill, USA

6. Lapolli F, Cruz CM, Motta CL, Tolla CE (2010) Modelo de Desenvolvimento de Objetos de Aprendizagem Baseado em Metodologias Ágeis e Scaffoldings. Revista Brasileira Informática na Educação 18(2):17-32

7. Chalegre VC, Santos WB, Souza LO, Muñoz HJ, Meira SRL (2010) Estudo de Caso da Utilização de Scrum no Desenvolvimento Distribuído de Software. In: Anais Workshop Brasileiro de Métodos Ágeis

8. Souza R (2014) Prática de Design Thinking. Subject Inovação em Projetos de Software. University of Federal Rural de Pernambuco, Recife

9. Macêdo LN, Macêdo A, Castro JA (2007) Avaliação de um objeto de aprendizagem com base nas teorias cognitivas. In: Anais do Workshop de Informática na Escola

10. Polsani P (2003) Use and abuse of reusable learning objects. J Digit Inf. https://journals.tdl.org/jodi/index.php/jodi/article/view/89/88, April

11. Wiley D (2000) Conectando Objetos de Aprendizagem com a teoria de projeto instrucional: uma definição, uma metáfora e uma taxonomia. http://penta3.ufrgs.br/objetosaprendizagem/11 wiley_traducao.doc. Accessed 6 Sept 2014

12. Calil FC, Peres HHC, Zaima J, Tobase $L$ (2012) A produção científica de objetos de aprendizagem no ensino em enfermagem. J Healthc Inf 4(Special Number - SIIENF 2012):138-43

13. Oliver R (2001) Learning objects: supporting flexible delivery of online learning. Centre for Research in Information Technology and Communications. Edith Cowan University, Australia

14. Engholm H. Jr. (2010) Engenharia de Software na Prática, 1a Edição, São Paulo: Editora Novatec

15. Soares M (2004) Comparação entre Metodologias Ágeis e Tradicionais para Desenvolvimento de Software. INFOCOMP J ComputSci 3(2):8-13

16. Beck K, Beedle M, Van Bennekum A, Cockburn A, Cunningham W, Fowler M, Kern J (2001) Manifesto for agile software development. http://www. agilemanifesto.org. Accessed 15 Jan 2015

17. Asfora D (2009) Uma abordagem para a priorização de requisitos em ambientes ágeis, Masters dissertation. University Federal of Pernambuco, Recife

18. Piccinini J (2013) Desenvolvimento de um repositório e jogos para o ensino do Scrum. Final Paper, University Federal of Santa Caratina, Florianópolis, Brazil, http://www.gqs.ufsc.br/wp-content/uploads/2011/11/JoaoPiccinini_ RelatorioTCC2_Final.pdf-content/uploads/2011/11/JoaoPiccinini_ RelatorioTCC2_Final.pdf. Accessed 29 Oct 2014.

19. Cavalcanti E, Maciel TMM, Albuquerque J (2009) Ferramenta Open-Source para Apoio ao Uso do Scrum por Equipes Distribuídas. In: Simpósio Brasileiro de Engenharia de Software. In: Anais II Workshop de Desenvolvimento Distribuído de Software

20. Schwaber K (2004). Agile project management with Scrum. Microsoft press

21. Fonseca AV, Miyake DI (2006) Uma análise sobre o Ciclo PDCA como um método para solução de problemas da qualidade. XXVI Encontro Nacional de Engenharia de Produção. pp. 1-9, Accessed 8 Apr 2014. http://www. abepro.org.br/biblioteca/ENEGEP2006_TR470319_8411.pdf

22. Costa AML (2010) A qualificação do serviço de apoio domiciliário, Master dissertation, Instituto Superior de Ciências Sociais e Políticas, Portugal., https://www.repository.utl.pt/bitstream/10400.5/3027/1/Disserta\%C3\% A7\%C3\%A30\%20Mestrado\%20Pol\%C3\%ADtica\%20Social.pdf. Accessed 12 Nov 2014

23. Moen R, Norman C (2006) Evolution of the PDCA cycle. http://pkpinc.com/ files/NA01_Moen_Norman_fullpaper.pdf, April.

24. Eriksson H, Penker M. (2000) Business Modeling with UML: Business Patterns at Work. New York: John Wiley \& Sons

25. Osterwalder A, Pigneur Y (2013) Business model generation: Inovação em Modelos de Negócios. Alta Books, Rio de Janeiro

26. BMG, Business Model Generation (2015), http://www.businessmodelgeneration. com. Accessed 3 Apr 2015

27. Capela L (2014) Especificação de uma Aplicação para Definição de Modelos de Negócio. Masters dissertation, University do Porto, Portugal. http://repositorio-aberto.up.pt/bitstream/10216/71526/2/45681.pdf. Accessed 21 Apr 2015

28. Oliveira S, Motta R, Oiveira A. (2012) Gestão de processos e tecnologia de informação: em busca da agilidade em serviço. Revista Eletrônica de Gestão Organizacional, v. 10, n. 1. 
29. Gonçalves J, Santoro FM, Amorim FAB (2010) Story mining: Elicitação de processos de negócio a partir de Group Storytelling e técnicas de mineração de texto, Master dissertation. UNIRIO/PPGI, Rio de Janeiro

30. OMG, Object Management Group (2014) Business process model and notation-BPMN. http://www.omg.org/spec. Accessed 28 Nov 2014.

31. Bonini L, Sbragia R (2011) O modelo de Design Thinking como indutor da inovação nas empresas: um estudo empírico. Revista de Gestão e Projetos-GeP 2(1):03-25

32. Amaral LL, Gomes TA, Souza MFC, Castro Filho JA, Pequeno MC (2006) Um aprimoramento do modelo de processo de criação de objetos de aprendizagem do projeto RIVED. In: Anais do Workshop de Informática na Escola, vol 1, i. 1

33. Pessoa MC, Benitti FB (2008) Proposta de um Processo para Produção de Objetos de Aprendizagem. In: Hifen, Uruguaiana, vol 32, i 62., pp 172-180

34. Branch R. (2009) Instructional design: The ADDIE approach (Vol. 722). Springer Science \& Business Media

\section{Submit your manuscript to a SpringerOpen ${ }^{\circ}$ journal and benefit from:}

- Convenient online submission

- Rigorous peer review

- Immediate publication on acceptance

- Open access: articles freely available online

- High visibility within the field

- Retaining the copyright to your article

Submit your next manuscript at $\gg$ springeropen.com 